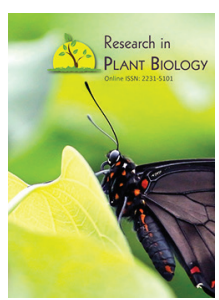

ISSN: $2231-5101$

\title{
Intra Specific Analysis of Gloriosa superba (L.) through ISSR finger printing and DNA sequencing of ecotypes collected from different accessions of Tamil Nadu State, India
}

\author{
J. A. Paul Jasmine', V. Balakrishnan ${ }^{1,2 *}$ \\ ${ }^{1}$ Research and Development Center, Bharathiar University, Coimbatore-641 046, Tamil Nadu, India. ${ }^{2}$ PG \\ and Research Department of Botany, Arignar Anna Government Arts College, Sanyasikaradu, \\ Namakkal - 637 002, Tamil Nadu, India
}

\begin{abstract}
Diversity within and among the population of Gloriosa superba collected from five different location of Tamil Nadu State, India, were explored by using Inter Simple Sequence Repeat (ISSR) DNA sequencing method. A total of 86.27\% of polymorphic bands were seen in 94 reproducible bands generated from 12 number of ISSR primer ranging between 200bp tol000bp of band width. ISSR primer produces the bands with an average polymorphism of more than ninety nine percent among all the ecotypes. The dendrograms drawn for the analysis of genetic similarity in all the ecotypes. Our studies reveals that, genetic variations among different accessions of Gloriosa superba $(L)$ was very well identified with the help of ISSR finger printings technic.
\end{abstract}

*Corresponding Author: Balakrishnan V

Email: palanivbalu@gmail.com

Received: February 28, 2018

Accepted: April 30, 2018

Published: May 01, 2018

KEYWORDS: Dendrogram, Gloriosa superba, accessions, ecotypes, genetic variation

\section{INTRODUCTION}

Gloriosa superba $(\mathrm{L})$ is an emerging medicinal plant belongs to the family Colchicaceae found widely throughout tropics and extends its occurrence in Africa, India and Southeastern Asia. The plant initially grown for its showy, broad and beautiful flower, locally named as "Senganthal malar" which is the state flower of Tamil Nadu State, India. Later the crop was evidenced to have high medicinal value both in formal and informal medicine. Its utility is pronounced both traditional and in modern medicine because of the high alkaloid accumulation in various parts of the plant.

The tuber portion of the plant contain two important alkaloids namely Colchicine $\left(\mathrm{C}_{22} \mathrm{H}_{25} \mathrm{O}_{6} \mathrm{~N}\right)$ and Colchicoside $\left(\mathrm{C}_{27} \mathrm{H}_{33} \mathrm{NO}_{11}\right)[1]$ which is used for curing cold, ulcers, hemorrhoids [2] but in the recent study which is used for the treatment of bruises and sprains, colic, chronic ulcer, haemorrhoids, cancer, impotence, nocturnal emission, skin diseases, snake bites, intermittent fever, leprosy and also for inducing labour pains and for abortions [3]. In modern medicine, thiocolchicoside a semi - synthetic derivative of cholchicoside is used as a muscle relaxant, analgetic and for anti inflammatory actions. Seeds and tubers of Gloriosa superba are used to treat gouts and rheumatism [4].
The genus Gloriosa comprises of about 10 to 15 known species apart from Gloriosa superba, viz. G. lulea, G.plantii, G. latifolia, G.longifolia, G.magnifica, G.rothschildiana, G.abyssinica, G. congijolia and G.simplex. In all these the important species found in India are G.superbaa and G. rothschidiana [5]. Its distribution spreads to Nasik, Ratnagiri, Savanthwadi (Maharastra), Uttar karnataka, Hasson, Chikmangalur, Coorg, Mysore (Karnataka), Cannanore Palakkad, Trivandrum (Kerala), Tamil Nadu and Goa. In Tamil Nadu the largest area are under hilly region and is up to 6000 acres and spread over seven district viz Karur, Tirupur, Dindigul, Salem, Ariyalur, Perembalur and Nagapattnam [6]. The planting of the crop is seasonal and it falls on the kharif month (June - July).

There is no specific released variety is available in this crop, only ecotypes with variable proportion of chemical constitutions in accumulation are available. This chemical constitution especially the alkaloid content were quantified and seems to be varying along its distribution and found very much influenced by the micro climatic factors of that particular accession. For further breeding and hybridization between natural populations, it is mandatory to known the genetic relationship that exists between the ecotypes of different accession, the identification

Copyright: $\odot 2018$ The authors. This article is open access and licensed under the terms of the Creative Commons Attribution License (http://creativecommons.org/licenses/by/4.0/) which permits unrestricted, use, distribution and reproduction in any medium, or format for any purpose, even commercially provided the work is properly cited. Attribution - You must give appropriate credit, provide a link to the license, and indicate if changes were made. 
of similarities and difference between the ecotypes taps the novel genes within the ecotypes for future research purpose.

ISSR- PCR has been widely used DNA-based molecular marker technique used to analyze the relationship between the species and ecotypes [7]. The characterization of accessions through finger printing can be very well done using ISSRPCR technique [8] among many types of DNA markers, the Inter simple sequence repeat (ISSR-PCR) can be very well utilized, as the ISSR distribution throughout the genome can be very well addressed by this technique. The marker based on microsatellites simple sequence repeats (SSRS) provides a co-dominate highly reproducible and genetically informative marker system [9].

But the loci of ISSR in the Gloriosa is unknown, this may be replaced by the advanced technique called ISSR- PCR technique, which has been found to be an efficient and reliable technique [10] as this technique need -no information on the DNA sequence prior to amplification, low cost, done with micro samples, perform with simple operations gives stability and produces abundance of genomic information.

Several factors are important including the geographic range which is strongly associated in determining the genetic diversity within the species it is also noted in this study that the general endemic species have lower genetic diversity than the wide spread species [11]. So, it is of great need to find a genetic marker for all the five ecotypes collected from different accessions of Tamil Nadu for authentication and standardization of chemical constituents for further clinical, pharmacological and research purpose through highly reliable ISSR-PCR marker Systems. The objective of the present study is to identify specific, effective and reproducible markers for five ecotype of Gloriosa superba (L) collected from different commercially cultivable accessions.

\section{MATERIALS AND METHODS}

\section{Planting Materials}

Ecotypes of Gloriosa superba (L) were taken from five different accessions from different regions such as Sirumalai (GA1), Mulanoor (GA2), Thuraiyur (GA3), Konganapuram (GA4) and Vedaranyam (GA5) for the investigation. The Randomized Block Design (RBD) with three replication was done. The experimental area mixed with red earth, sand, vermicompost and farmyard manure in the ratio of 1:1:1:1 was applied in the agriculture field in order to enhance the micro and macro nutrient of the soil for better plant growth. The plots were irrigated at seven to ten days interval regularly, the recommended agronomic and plant protection methodology were implemented during the cultivation.

\section{Genetic Variability Studies And Separation Of DNA}

Genetic variability studies for five ecotypes from 5 different accessions. Samples taken from five different accessions were used for the present studies (The reagents used to amplify the genomic DNA for ISSR analysis is given in the Table-1) and the DNA was extracted from bulk, fresh leaf tissues from each population of Gloriosa superba (L) as per the procedure [12] and the DNA was assessed by UV-vis spectrophotometer (Techomp 8500) in order to find out the purity and the quantity of DNA [13] and the DNA were separated by electrophoresis in agarose gel (1.0\%) and was visualized by UV-vis trans illuminator and photographed. DNA pooling was done by pooling equal amount of purified economic DNA from the individuals of each five species and aliquot from those combined sample was used for PCR.

\section{Inter Simple Sequence (ISSR Analysis)}

The genetic variability studies were conducted by ISSR analysis using modified method [10].Earlier twenty primers were tested and twelve primers producing reproducible bands were selected for five accessions. Primers representing different random knock out DNA sequences were issued for ISSR-assay. The experiment were repeated three times and conformed for the reproducibility of bands the amplified products were checked by running through $1.5 \%$ agarose gel stained with ethidium bromide, the gel was viewed using UV-trans-illuminator and gel was documented using photo documentation system. The banding patterns were analyzed.

\section{Inter Simple Sequence (ISSR Analysis)}

The genetic variability studies were conducted by ISSR analysis by using modified method [10]. Earlier twenty primers were tested and in which twelve primers producing reproducible bands were selected for the five accessions. Primers representing different random knock out nucleotide sequences were repeated three times for confirmation of the reproducibility of bands. An initial denaturing period of $2 \mathrm{~min}$ at 94degree was followed by 35 cycles of $30 \mathrm{sec}$ at 94degree and then 35 cycles for $45 \mathrm{sec}$ at 42 degree followed by 35 cycles of $1 \mathrm{~min}-30 \mathrm{sec}$ at 72 degree for final extension was done (Table 2). The reaction was done with $25 \mu \mathrm{l}$ containing about $15.9 \mu \mathrm{l}$ of sterile water, $4 \mu \mathrm{l}$ of $\mathrm{dNTPS}, 1.5 \mu \mathrm{l}$ of $\mathrm{Mgcl} 2 ., 1 \mu \mathrm{l}$ of Taq polymerized and $0.5 \mu \mathrm{l}$ of plant DNA. The amplified products were checked by running through $1.5 \%$ agrosegel stained with ethidium bromide. The gel was viewed using UV-Tran-illuminator and the gel was documented using photo documentation system. The banding patterns were analyzed for knowing the similarities and difference between the ecotypes. Out of 20 primers, 12 reproduced primers were chosen for running ISSR-PCR analysis (Table 3).

Table 1: Reagents used to amplify the genomic DNA for ISSR analysis

\begin{tabular}{|c|c|c|}
\hline S.No. & Constituents & Quantity \\
\hline 1. & Sterile water & $15.9 \mu \mathrm{l}$ \\
\hline 2. & dNTPs & $4.0 \mu \mathrm{l}$ \\
\hline 3. & $\mathrm{MgCl} 2$ & $1.5 \mu \mathrm{l}$ \\
\hline 4. & 10X PCR Buffer & $2.5 \mu \mathrm{l}$ \\
\hline 5. & Primers & $0.5 \mu \mathrm{l}$ \\
\hline 6. & Taq polymerase & $0.1 \mu \mathrm{l}$ \\
\hline 7. & Plant DNA & $0.5 \mu \mathrm{l}$ \\
\hline Total & & $25.0 \mu \mathrm{l}$ \\
\hline
\end{tabular}




\section{Data Analysis}

The genetic distance matrix was obtained and analyzed through cluster method inorder to construct the UPGMA (Unweighted Pair Group method with Arithmetic mean Dendrogram using MEGA 4.0 [14].

\section{RESULTS AND DISCUSSION}

\section{ISSR Polymorphism}

Earlier twenty primers were taken and screened for the studies. Primer producing clear and reproducible bands of 12 numbers were selected for further amplification with genome of five ecotypes of Gloriosa Superba (L).The oligonucleotide sequence of the primer with the percent content along with the amplification temperature were taken and their appropriate sequences were used for the analysis of ISSR. The twelve primers on amplification produces 7.8 bands per primer. The size range varies between $200 \mathrm{bp}$ to $1000 \mathrm{bp}$ and a total of 94 polymorphic fragments were produced for all the five ecotypes of Gloriosa superba (L) which were summarized.

\section{Genetic Diversity}

The 5' anchored primers produces total of 94 polymorphic fragments in which the total diversity $(\mathrm{Hg})$ varies between 0.2479 and 0.4880 , and diversity within the population (Hs) varies between 0.0924 and 0.1984 . The genetic differentiation (gst) of the produced fragment population range within 0.4418 to 0.8436 with a range of $0.2179-0.6387$ of gene flow $(\mathrm{Nm})$ $(\mathrm{Hr}, \mathrm{Hs}$, Gst and $\mathrm{Nm}$ ) With the mean average of 1.9647 numbers

Table 2: Conditions followed for ISSR - PCR analysis and the reaction steps

\begin{tabular}{llccc}
\hline S.No. & Activity & Temperature & Time & Cycles \\
\hline 1. & Initial denaturation & $94^{\circ} \mathrm{C}$ & $2 \mathrm{~min}$ & One \\
2. & Denaturation & $94^{\circ} \mathrm{C}$ & $30 \mathrm{sec}$ & 35 \\
3. & Annealing & $42-46^{\circ} \mathrm{C}$ & $45 \mathrm{sec}$ & \\
4. & Extension & $72^{\circ} \mathrm{C}$ & $1 \mathrm{~min} .30 \mathrm{sec}$ & \\
5. & Final Extension & $72^{\circ} \mathrm{C}$ & $20 \mathrm{~min}$ & One \\
6. & Storage & $4^{\circ} \mathrm{C}$ & For ever & \\
\hline
\end{tabular}

Table 3: ISSR-primers used for ISSR-PCR analysis of five accessions of Gloriosa superba (L)

\begin{tabular}{lcccc}
\hline S.No. & Primers & Sequence 5'-3' $^{\prime}$ & GC content (\%) & Temperature $\left(\mathrm{C}^{0}\right)$ \\
\hline 1. & HBI0809 & (AG) 8G & 52.9 & 52.8 \\
2. & HBI0810 & (GA) 8T & 47.1 & 50.4 \\
3. & HBI0812 & (GA) 8A & 47.1 & 50.4 \\
4. & HBI0816 & (CA) 8T & 47.1 & 50.4 \\
5. & HBI0834 & (AG) 8T & 47.2 & 52.6 \\
6. & HBI0835 & (AG) 8C & 52.9 & 52.8 \\
7. & HBI0836 & (AG) 8A & 47.1 & 50.4 \\
8. & HBI0840 & (GA) 8T & 47.1 & 50.4 \\
9. & HBI0842 & (GA) 8G & 52.9 & 52.8 \\
10. & HBI0855P & (8TG) 6 & 51.6 & 46.9 \\
11. & HBI0864 & (CTC) 6 & 33.3 & 48.7 \\
12. & HBI0873P & (GACA) 4 & 49.2 & 50.2 \\
\hline
\end{tabular}

of alleles, a mean average of 1.6471 numbers of alleles were found to be effective. The mean Nei's gene diversity between GAlGA5 were $0.0931,0.1477,0.1285,0.1193$ and 0.1013 respectively, with an average mean value of 0.4041 as shown (Table 4). Nei's Unbiased measures of genetic identity (above diagonal) and genetic distance (below diagonal) were shown (Table 5). Genetic distance of all loci between the population obtained by assessing the ISSR-PCR banding pattern shown in table 6 . The Similarity matrix shows a maximum similarity of (0.9276) that occurs between GAl and GA5and a minimum similarity of (0.6307) that occurred between GA2 and GA3 which is given in the similarity matrix (Table 7).The number of polymorphic loci in all the five ecotypes varies between 26 (GAl) to 45(GA3), and the percentage of polymorphism varies from $26.36 \%$ (GAl) to 40.64 (GA3) which were represented (Table 8). The value of total number of observed alleles(na), Effective number of alleles(ne), Nei's gene diversity (h), Shannan's information index (I) were given as $1.9647,1.6471,0.4041,0.5607$ respectively and the over all polymorphic loci and its percentage were given as 92 and 86.27 respectively were given in Table 9 .

The genetic relationship between five ecotypes was arrived by closing it into groups by UPGMA analysis based on Nei's genetic diversity within the population. A dendrogram was generated based on the cluster analysis through which the genetic relationship between the ecotypes can very well be studied. The genetically, ecotypes of GA4 and GA5 were closely related and ecotypes of GA3 and GA2 are widely placed, which were shown in dendrogram (Figure 1).

\section{DISCUSSION}

It is of urgent need to standardize and authenticate the chemical constituents of Gloriosa superba(L) ecotypes obtained from various accessions of Tamil Nadu as it varies with varying geological and agroclimatic conditions. Earlier work on Gloriosa superba (L) was done with ISSR-PCR system to evaluate genetic fidelity of micro propogated Gloriosa superba $(\mathrm{L})$ using ISSR marker [15] was seems to be single work regarding genetic studies of the plant.

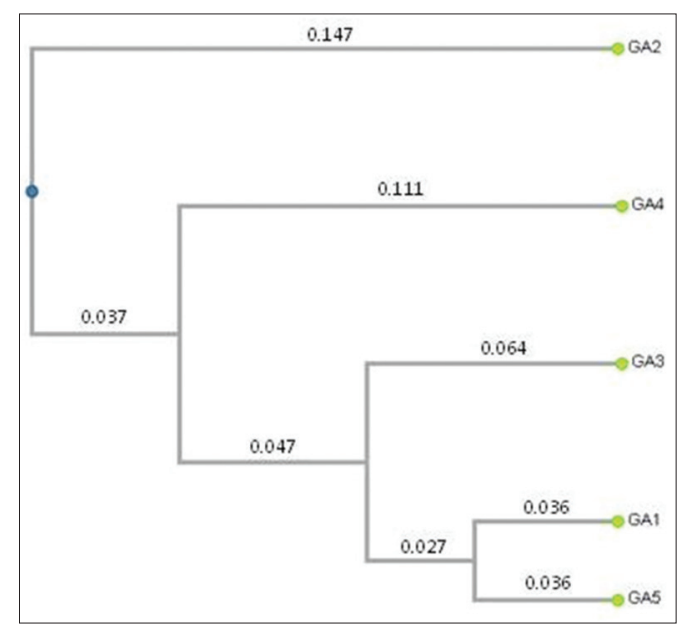

Figure 1: UPGMA dendrogram of Gloriosa superba accessions for ISSR analysis 
Table 4: Gene diversity within and between the populations of five accessions of G.superba

\begin{tabular}{|c|c|c|c|c|c|c|c|}
\hline S.No & Primers & $\begin{array}{l}\text { Annealing } \\
\text { Temp. } \\
\left(C^{0}\right)\end{array}$ & $\begin{array}{l}\text { No. of polymorphic } \\
\text { fragments }\end{array}$ & $\begin{array}{c}\text { Total } \\
\text { diversity }\left(\mathrm{H}_{\mathrm{T}}\right)\end{array}$ & $\begin{array}{c}\text { Genetic diversity within } \\
\text { population } \\
\left(\mathrm{H}_{\mathrm{s}}\right)\end{array}$ & $\begin{array}{c}\text { Genetic } \\
\text { differentiation }\left(\mathrm{G}_{\mathrm{ST}}\right)\end{array}$ & $\begin{array}{l}\text { Gene flow } \\
\left(N_{m}\right)\end{array}$ \\
\hline 1 & HBI0809 & 44 & 8 & 0.4158 & 0.1658 & 0.6587 & 0.4238 \\
\hline 2 & HBI0810 & 43 & 5 & 0.3458 & 0.0924 & 0.4418 & 0.3343 \\
\hline 3 & HBI0812 & 47 & 11 & 0.2510 & 0.0945 & 0.5444 & 0.2179 \\
\hline 4 & HBI0816 & 42 & 6 & 0.3203 & 0.1584 & 0.5389 & 0.4024 \\
\hline 5 & HBI0834 & 46 & 5 & 0.2479 & 0.1065 & 0.5120 & 0.2756 \\
\hline 6 & HBI0835 & 44 & 9 & 0.4789 & 0.1541 & 0.6173 & 0.4891 \\
\hline 7 & HBI0836 & 45 & 9 & 0.3178 & 0.1283 & 0.5410 & 0.3387 \\
\hline 8 & HBI0840 & 42 & 11 & 0.4732 & 0.1074 & 0.6613 & 0.4047 \\
\hline 9 & HBI0842 & 46 & 5 & 0.3496 & 0.1335 & 0.6337 & 0.6387 \\
\hline 10 & HBI0855P & 41 & 8 & 0.4880 & 0.1787 & 0.8436 & 0.3001 \\
\hline 11 & HBI0864 & 46 & 9 & 0.3778 & 0.0934 & 0.5454 & 0.2419 \\
\hline 12 & HBI0873P & 43 & 8 & 0.3307 & 0.1984 & 0.7896 & 0.3951 \\
\hline
\end{tabular}

Table 5: Nei's Unbiased measures of genetic identity (above diagonal) and genetic distance (below diagonal)

\begin{tabular}{|c|c|c|c|c|c|c|c|c|c|}
\hline \multirow[t]{2}{*}{ S. No } & \multirow[t]{2}{*}{ Accessions } & \multicolumn{2}{|c|}{$\begin{array}{l}\text { Observed number of alleles } \\
\text { (na) }\end{array}$} & \multicolumn{2}{|c|}{$\begin{array}{l}\text { Effective number of alleles } \\
\text { (ne) }\end{array}$} & \multicolumn{2}{|c|}{ Nei's gene diversity (h) } & \multicolumn{2}{|c|}{$\begin{array}{c}\text { Shannon's information } \\
\text { index (I) }\end{array}$} \\
\hline & & Mean & Standard deviation & Mean & Standard deviation & Mean & Standard deviation & Mean & Standard deviation \\
\hline 1 & $\mathrm{GA}_{1}$ & 1.5364 & 0.5268 & 1.2632 & 0.4214 & 0.0931 & 0.1643 & 0.2368 & 0.3521 \\
\hline 2 & $\mathrm{GA}_{2}$ & 1.4209 & 0.5871 & 1.2246 & 0.4181 & 0.1477 & 0.1706 & 0.2086 & 0.3679 \\
\hline 3 & $\mathrm{GA}_{3}^{2}$ & 1.3545 & 0.5712 & 1.3138 & 0.4255 & 0.1285 & 0.1621 & 0.1932 & 0.3681 \\
\hline 4 & $\mathrm{GA}_{4}$ & 1.6882 & 0.5679 & 1.2030 & 0.4323 & 0.1193 & 0.1731 & 0.2777 & 0.3674 \\
\hline 5 & $\mathrm{GA}_{5}$ & 1.4123 & 0.5426 & 1.2749 & 0.4231 & 0.1013 & 0.1967 & 0.2498 & 0.3570 \\
\hline
\end{tabular}

Table 6: Genetic distance between the populations obtained by assessing the ISSR-PCR banding pattern of Gloriosa superba (L) from five accessions.

\begin{tabular}{lccccc}
\hline Accessions & $\mathrm{GA}_{1}$ & $\mathrm{GA}_{2}$ & $\mathrm{GA}_{3}$ & $\mathrm{GA}_{4}$ & $\mathrm{GA}_{5}$ \\
\hline $\mathrm{GA}_{1}$ & 1.000 & & & & \\
Accessions & $\mathrm{GA1}$ & $\mathrm{GA} 2$ & $\mathrm{GA} 3$ & $\mathrm{GA} 4$ & $\mathrm{GA} 5$ \\
$\mathrm{GA}_{2}$ & 0.854 & 1.000 & & & \\
$\mathrm{GA}_{3}$ & 0.509 & 0.504 & 1.000 & & \\
$\mathrm{GA}_{4}$ & 0.644 & 0.473 & 0.518 & 1.000 & \\
$\mathrm{GA}_{5}$ & 0.781 & 0.618 & 0.653 & 0.810 & 1.000 \\
\hline
\end{tabular}

Table 7: Similarity matrix obtained by assessing the ISSR-PCR banding pattern of five ecotypes of Gloriosa superba (L).

\begin{tabular}{lccccc}
\hline Accessions & $\mathrm{GA}_{1}$ & $\mathrm{GA}_{2}$ & $\mathrm{GA}_{3}$ & $\mathrm{GA}_{4}$ & $\mathrm{GA}_{5}$ \\
\hline $\mathrm{GA}_{1}$ & $* * * *$ & 0.7510 & 0.8840 & 0.7877 & 0.9276 \\
$\mathrm{GA}_{2}$ & & $* * * *$ & 0.6307 & 0.6900 & 0.7509 \\
$\mathrm{GA}_{3}$ & & & $* * *$ & 0.6627 & 0.8614 \\
$\mathrm{GA}_{4}$ & & & & $* * * *$ & 0.8862 \\
$\mathrm{GA}_{5}$ & & & & & $* * * *$ \\
\hline
\end{tabular}

Table 8: Analysis of polymorphism of five accessions of Gloriosa superba (L)

\begin{tabular}{llcc}
\hline S.No. & $\begin{array}{l}\text { Number of } \\
\text { accessions }\end{array}$ & $\begin{array}{c}\text { Number of polymorphic } \\
\text { loci }\end{array}$ & $\begin{array}{c}\text { Percentage of } \\
\text { polymorphism }\end{array}$ \\
\hline 1 & $\mathrm{GA}_{1}$ & 26 & 26.36 \\
2 & $\mathrm{GA}_{2}$ & 29 & 27.09 \\
3 & $\mathrm{GA}_{3}$ & 45 & 40.64 \\
4 & $\mathrm{GA}_{4}$ & 39 & 35.82 \\
5 & $\mathrm{GA}_{5}$ & 38 & 32.45 \\
\hline
\end{tabular}

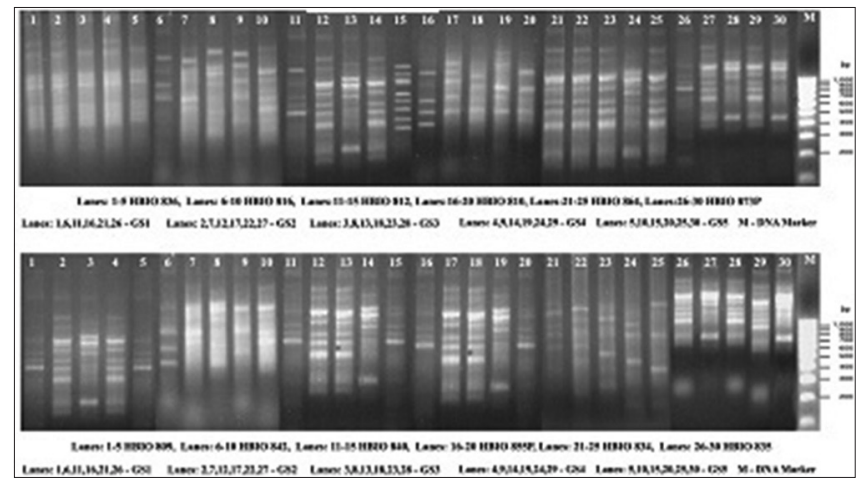

Figure 2: ISSR banding pattern of Gloriosa superba (L).obtained from five different accessions obtained using 12 reproducible primers.

In the present study reveals that the ISSR-PCR system was taken as tool for analyzing the genetic diversity (Figure 2). Twelve number of 5' sequence anchored primer were selected as it produces clear and reproducible fragments, about the 20 primers were taken initially and they were amplified. The ISSR marker technique produces much greater number of total polymorphic and discrimitant fragments then RAPDS [16] and lower cost than AFLPS [17]. Simpler to use than SSR technique [18]. Molecular fingerprints of four different species of Curcuma amada, C.caesia, C.longa and C.zedoa [19].Similar results are also reported in three different DNA based technique such as RAPD, ISSR and AFLP were used for fingerprinting Dactylis glomerata genotype and for detecting genetic variation between the three subspecies [20]. Various species of genus Saccharina are economically important brown algae cultivated in China. 
Table 9: The mean Nei's gene diversity, Shannan's index and polymorphic loci of five accessions

\begin{tabular}{|c|c|c|c|c|c|c|c|c|c|c|}
\hline \multirow[t]{2}{*}{ S.No. } & \multicolumn{2}{|c|}{$\begin{array}{l}\text { Observed number of } \\
\text { alleles (na) }\end{array}$} & \multicolumn{2}{|c|}{$\begin{array}{l}\text { Effective number of } \\
\text { alleles (ne) }\end{array}$} & \multicolumn{2}{|c|}{$\begin{array}{l}\text { Nei's gene diversity } \\
\text { (h) }\end{array}$} & \multicolumn{2}{|c|}{$\begin{array}{c}\text { Shannan's information } \\
\text { index (I) }\end{array}$} & \multirow[t]{2}{*}{ Over all polymorphic loci } & \multirow[t]{2}{*}{$\begin{array}{l}\text { Over all percentage of } \\
\text { polymorphic loci }\end{array}$} \\
\hline & Mean & $\begin{array}{l}\text { Standard } \\
\text { deviation }\end{array}$ & Mean & $\begin{array}{l}\text { Standard } \\
\text { deviation }\end{array}$ & Mean & $\begin{array}{l}\text { Standard } \\
\text { deviation }\end{array}$ & Mean & $\begin{array}{l}\text { Standard } \\
\text { deviation }\end{array}$ & & \\
\hline 1 & 1.9647 & 0.4348 & 1.6471 & 0.4990 & 0.4041 & 0.2481 & 0.5607 & 0.3045 & 92.0 & 86.27 \\
\hline
\end{tabular}

DNA based molecular markers such as ISSR to assess the genetic diversity and phylogentic relationships [21].

The ISSR produced fragment shows a $86.27 \%$ of polymorphism within 94 reproducible polymorphic fragment, which shows that the inter simple repeat sequences spreads throughout the genome of all the five ecotypes. Similarly high polymorphic fragments were obtained by many workers in so many plants especially in olive, with varying results of 93\% [22], 96\% [23] when the gene analysis were done with ISSR-PCR system. An average mean of 1.6471 effective number of alleles (ne) were obtained from the average means of 1-9647 number of observed alleles (na). Supporting the identification of novel alleles for further research purposes. Average mean of 0.4041 Nei's gene diversity (h) was arrived using which the dendrogram was constructed using cluster analysis, to find the genetic relationship between the five ecotypes and useful ideal reaction. However, ISSR is a better tool than RAPD for phylogenetic analysis [24, 25]. Methods used to preserve the samples can provides sufficient amount of genomic DNA for ISSR and RAPD analysis [26].

Based on the reproducibility, relatively high polymorphisms were selected generally in optimal condition. Moreover, reliable ISSR-PCR-method for Gloriosa superba (L) and established by analyzing amplified bands then successful ideal reaction.

\section{ACKNOWLEDGEMENTS}

The authors are thankful to the farmer Mr. M. Selvaraj, for providing all the facilities for the cultivation of experimental plant Gloriosa superba (L).

\section{REFERENCES}

1. Sivakumar G, Krishnamurthy KV, RajendranTD. Embryoidogenesis and plant regeneration form leaf tissues of Gloriosa superba. Planta Med. 2003; 69:479-481.

2. Kala CP. Indigenous uses and sustainable harvesting of trees by local people In the Pachamarhi Biosphere reserve of India. Int. J. Med, Arom. Plants. 2011;1(2):153-161.

3. Gupta LM, Raina RC,Raina R,Gupta M. Colchicine content in Gloriosa superb L.J. Res. SKUAST-J, 2005; 4(2): 238-241.

4. Trease SE, Evans D. Colchicum seed and corm. In: Pharmacognosy, $12^{\text {th }}$ cdn. Balliere Tindall, London, 1983:593-597.

5. Tarar JL, Vishwakarma M. Chromosome of diploid and tetraploid. Gloriosa superba Linn, In: padhyge M.D, Mlukherjee PK. Khalarkar AS (Eds) Botany towards 2000 A.D. (prof. VR Dhyansagar commemoration volume) Vedams Book, new Delhi, India, 1995: 280.

6. Padmapriya S, Rajamani K, Sathiyamurthy V.A. International Journal of Current Pharmaceutical Review and Research. 2015;7 (1): 43-49.

7. Salimath SS, de oliveriaAC, Godwin ID, Bennetzen JL. Assessment of genome origins and genetic diversity in the genus Eleusine With DNA markers. Gcnome.1995;3A: 757-763.
8. Tsumura Y, ohba K, Strauss SH. Diversity and inheritance of inter simple sequence repeat polymorphisms in dougla's fir (Pseudotsuga menziesii) and sugi (Cryptomria japonica).Theor. Appl. Genet. 1996;92:40-45

9. Fang DQ, Krueger RR, Roosc ML. Phylogentic relationships among selected citrus germplasm accessions revealed by inter simple sequence repeat (ISSR) Markers. J.AM.SC. Hort. Sci. 1998; 123: 612-617.

10. Zikejkiewiez E, Rafalski A, Labuda D. Genome finger printing by simple sequence repeat (SSR) - anchored Polymerase chain reaction amplification. Genomics. 1994; 20: 176-183.

11. Hamrick JL, God MJ, Murawski DA. Correlation between species and allozyme diversity implications for conservation biology. In Falk DA, Holsinger KE (Eds). Genetics and conservation of rare plants (Oxford University Press, New York, 1991. 75-86.

12. Doyle JJ, Doyle JL. Isolation of plant DNA from fresh tissue. Focus, 1990;12:13-15

13. Sambrook J, Fritsch EF, Manlatis T. Molecular cloning: a laboratory manual. Cold Spring Harbour.USA: cold spring harbor laboratory Press, 1989.

14. Tamura K, Dudley J,Nei M, Kumar S. MEGA4. Molecular evolutionary Genetics Analysis (MEGA) software version 4.0.Mol.Biol. 2007; 24:1596-1599.

15. Kuldeep Y, Ashok A, Narender S. Evaluation of genetic fidelity amoung micro propagated plants of Gloriosa superba (L) using DNA - based markers - a potential medicinal plant. Fitoterpia.2013; 89: $265-270$.

16. Tian XL, XVe JH, Wen J. Genetic diversity and relationships of lotus (nelumbo) cultivars based on allozyme and ISSR markers. Sci and Hortic. 2008:02:011

17. Reddy MP, Sarla N, Sidding EA. Inter simple sequence repeat (ISSR) polymorphism and its application in plant breeding. Euphytica. 2002; 128: 9-17.

18. Wolfe AD, Listen A. Contributions of pcr - based methods to plant Systematic and evolutionary Biology. In: solit is DE, Soltisps, oyle JJ (Eds) plant molecular systematics II kluwer, Boston,1998,43-86.

19. Saha K, Sinha S, Busak S, Sinha S. ISSR fingerprinting to ascertain the genetic relationship of Curcurma sp.f.Tripura. American Journal of Plant Sciences.2016;7:259-266.

20. Costa R,Graca P, Garrido I, Manuel MT. AFLP Molecular markers to reveal and classify orchard grass (Dactylis glomerala.L.) germplasm variations. Plosoue. 2016;11(4):e0152972.

21. Cui C, Li Y, Li X, Luo S, Zhang Z, Wu R, Liang G, Sun J, Peng J, Tian P. Determination of genetic diversity amoung Saccharina germplasm using ISSR and RADP markers. Comlies Redus Biologies. 2017:40(2):76-86.

22. Gilbert JE, Lewis RV, Wilkinson MI. Developing an appropriate strategy to assess genetic variability in plant germplasm collections. Theor. Appl. Genet. 1999; 98(6-7): 1125-1131.

23. Terzopoulus PJ, Kolano B, Bebel PJ. Identification of Olea europeace L. cultivar using inter simple sequence repeat markers. Scientia Horticulture. 2005;105:45-51

24. Ajibade SR, Weeden NF, Michite S. Inter simple sequence repeat analysis of Genetic relationships in the genus Vigna. Euphytica. 2000;111(1):47-55

25. Galvan MZ, Bornet B, Balatti PA, Branchard M. Inter simple sequence repeat (ISSR) marker as a tool for the assessment of both genetic diversity and gene pool origin in common bean (Phaseolus vulgaris L.).Euphytica.2003;132 (3):297-301.

26. Wang X, Lin L,Zhao J,Li F,GuoW, Chem X. Effect of different preservation on inter simple sequence repeat (ISSR)and random amplified polymorphic DNA(RADP)molecular markers in botanic samples. Comptes Rendus Biologies. 2017; 340(4):204-213 